\title{
Pearl Millet for the Management of Pratylenchus penetrans in Flue-Cured Tobacco in Quebec
}

Guy Bélair, Nathalie Dauphinais, and Yvon Fournier, Horticulture Research and Development Centre, Agriculture and Agri-Food Canada, St-Jean-sur-Richelieu, Quebec, Canada J3B 3E6; and Om P. Dangi, Agriculture Environmental Renewal Canada Inc. (AERC), Ottawa, Ontario, Canada K2E 7J6

\begin{abstract}
Bélair, G., Dauphinais, N., Fournier, Y., and Dangi, O. P. 2004. Pearl millet for the management of Pratylenchus penetrans in flue-cured tobacco in Quebec. Plant Dis. 88:989-992.

Two 1-year rotation experiments were conducted from 1998 to 2000 to assess the impact of forage and grain pearl millet (Pennisetum glaucum) on Pratylenchus penetrans populations in a tobacco field (Nicotiana tabacum cv. Delgold) in Quebec. Performance of these crops was compared with rye, the standard rotation crop. Rye plots were doubled to include a fumigated standard (application of metham sodium at 67.4 liters/ha on a band). Forage pearl millet increased tobacco yields by an average of $103 \%$ compared with nonfumigated rye. In 2000, leaf dry weights of tobacco following grain pearl millet CGPM H5 and CGPM H6 was increased by 70 and $73 \%$, respectively, when compared with nonfumigated rye and were not significantly different from the fumigated plots following rye. Forage and grain pearl millet should be considered as a viable alternative to fumigation for controlling $P$. penetrans infestation in flue-cured tobacco production in Quebec.
\end{abstract}

The root-lesion nematode, Pratylenchus penetrans (Cobb) Filipjev \& Schuur. Stekh., is a serious pest of many crops in North America. In eastern Canada, this endoparasitic nematode causes substantial economic losses in high-value crops $(1,4,6,8,10,12,15,16)$. In Quebec, economically damaging population densities of $P$. penetrans have been recorded on tobacco (Nicotiana tabacum L.) (11).

In eastern Canada and Quebec, rye (Secale cereale L.) is commonly grown in rotation with flue-cured tobacco. It has been demonstrated that rye is a good host of the root-lesion nematode $(3,5,14)$, so its use as rotation crop increases nematode populations on subsequent crops, thereby potentially decreasing yields. The reliance on soil fumigation with chemicals such as metham sodium is a common practice in Quebec to control preplant populations of $P$. penetrans and increase tobacco yields. The use of crops that are unfavorable for the root-lesion nematode may help to reduce or eliminate the use of nematicide in these soils. Forage and grain hybrids of

Corresponding author: G. Bélair

E-mail: belairg@agr.gc.ca

Contribution No. 335/2004.06.03R of the Horticulture Research and Development Centre, Agriculture and Agri-Food Canada, St-Jean-sur-Richelieu, Canada J3B 3E6.

Accepted for publication 27 April 2004.

Publication no. D-2004-0628-02R

(C) 2004 Department of Agriculture and Agri-

Food, Government of Canada pearl millet (Pennisetum glaucum L.) have been developed by Agriculture Environmental Renewal Canada (AERC Inc., Ottawa, Ontario). The principal distinguishing characteristics of grain pearl millet are its dwarf stature, early maturity, and grain yield. Forage pearl millet is highly photoperiod sensitive and produces high yields of green fodder with good forage quality. Both grain and forage type hybrids developed by AERC are well adapted to climatic and soil conditions of eastern Canada. These hybrids were shown to be poor hosts of $P$. penetrans in both greenhouse and field conditions in Canada $(1,3,6,7)$.

The objective of this research was to assess the impact of forage pearl millet and grain pearl millet on populations of $P$. penetrans and their impact on subsequent flue-cured tobacco yields in Quebec.

\section{MATERIALS AND METHODS}

From 1998 to 2000, two 1-year crop rotation experiments were conducted on one experimental site at St-Étienne-des-Grès, Quebec $\left(46^{\circ} 26^{\prime} \mathrm{N} ; 72^{\circ} 46^{\prime} \mathrm{W}\right)$, on a sandy soil ( $85 \%$ sand, $8 \%$ silt, $7 \%$ clay, and $5.2 \%$ organic matter). Trial 1 was carried out from 1998 to 1999 and trial 2 from 1999 to 2000. In both trials, rotation crops were planted the first year and tobacco was grown the following year as the high-value crop. Trials were carried out in adjacent fields on the same farm, and tobacco was the previous crop. In both trials, five treatments were arranged in a randomized complete block design with four replications. The crops in trial 1 were forage pearl millet (hybrid CFPM 101), grain pearl millet (hybrid CGPM H6), grain sorghum (cv. GS7), and rye (cv. Musketeer). Because grain sorghum was shown to be a good host of the root-lesion nematode, it was replaced by an early maturing grain pearl millet hybrid (CGPM H5) in trial 2. Rye, which promotes an increase in populations of the root-lesion nematode, was used as our positive control crop.

Eight plots of rye were included in the first year of each trial. Four of these plots were fumigated prior to planting tobacco and four were not fumigated. Tobacco and rye seeds were obtained from local seed suppliers, and pearl millet hybrid and grain sorghum seeds were provided by AERC. Forage and grain pearl millet hybrids were selected based on their performance, as genotypes that suppressed $P$. penetrans populations in a greenhouse screening study (7). In both trials, the four rye plots were fumigated with metham sodium (Vapam) at 67 liters/ha on 28 April 1999 (trial 1) and on 24 April 2000 (trial 2). The fumigant was injected at the $15-\mathrm{cm}$ depth using a 4-row John Blue applicator equipped with one injector per row. Soil temperature was approximately $9^{\circ} \mathrm{C}$ at injection depth.

Plots were $6.1 \mathrm{~m}$ wide $\times 14 \mathrm{~m}$ long. In both trials, plots were sown with fall rye the year before the trial; and the following spring, plots to be sown to millet or sorghum were plowed 1 week before sowing. For trial 1, millet and sorghum were sown on 2 June 1998 and received $300 \mathrm{~kg} / \mathrm{ha} \mathrm{N}$ P-K (23-11-20) fertilizer. A second planting was done on 13 July 1998 due to the poor establishment of the first seedlings. Millet and sorghum were sown with a 15$\mathrm{cm}$ row spacing. Hybrids CFPM 101 and CGPM H6 were planted using a seed rate of 6 and $5 \mathrm{~kg} / \mathrm{ha}$, and grain sorghum CGS 7 was planted at $14 \mathrm{~kg} / \mathrm{ha}$ to obtain a plant population of 150,000 plants per ha. The fall rye was densely planted using a seed rate of $120 \mathrm{~kg} / \mathrm{ha}$, which is similar to the traditional practice. In trial 2, millets were sown on 7 June 1999 and received 300 $\mathrm{kg} / \mathrm{ha}$ N-P-K (34-0-0 and 10-10-20) fertilizer 1 week before sowing. In 1999, the seeding rate of all pearl millet hybrids was increased by $30 \%$ due to low germination recorded the previous year. Populations of grain pearl millet hybrids (seed rate of approximately $7 \mathrm{~kg} / \mathrm{ha}$ ) were about 265,000 plants per ha, and forage pearl millet $(10 \mathrm{~kg} / \mathrm{ha})$ was about 388,000 plants per ha. Seeding rate used for rye was simi- 
lar to that in trial 1. In both trials, weeds were controlled manually several times during the season. Two cuts of the forage CFPM 101 were performed annually; one cut on the last week of July and a second on the second week of September. Each time, the forage was chopped and left on the soil. Rotation crops were incorporated as green manure by plowing in early October.

In trial 1 , tobacco seedlings (Nicotiana tabacum L. cv. Delgold) were transplanted on 15 May 1999, $56 \mathrm{~cm}$ apart within a row and $107 \mathrm{~cm}$ between rows. In trial 2, seedlings were transplanted on 7 June 2000, 61 $\mathrm{cm}$ apart within a row and $107 \mathrm{~cm}$ between rows. All plots were fertilized with a broadcast application of 3-10-20 (4\% Mg, $5 \% \mathrm{Ca}$ ) at $1,188 \mathrm{~kg} / \mathrm{ha}$ before transplanting. Plots also received $224 \mathrm{~kg} / \mathrm{ha}$ of $3-10-$ 20 at transplanting and $224 \mathrm{~kg} / \mathrm{ha}$ of $3-0$ 20 (50\% calcium nitrate) on the last week of June.

Tobacco yields were collected based on biomass, but quality evaluations were not conducted. Leaf yield was determined by harvesting two tobacco plants per plot for trial 1 and six plants per plot for trial 2 . Leaves were cut from the stem, and both were dried for 3 days at $65^{\circ} \mathrm{C}$. Yield was expressed as dry weight in $\mathrm{kg} / \mathrm{ha}$. Plant height and number of leaves per plant were recorded by examining 10 arbitrarily chosen tobacco plants per plot for trial 1 and
36 plants for trial 2. Leaf width and length were recorded in trial 2. Tobacco yields were recorded on 29 July 1999 (trial 1) and on 8 August 2000 (trial 2).

Soil and root samples were collected at each site to assess population densities of $P$. penetrans. Sampling dates were 2 June 1998, 29 July 1998, 16 October 1998, 19 May 1999, 29 July 1999, and 8 September 1999 for trial 1, and 19 May 1999, 29 July 1999, 8 September 1999, 15 June 2000, 8 August 2000, and 29 September 2000 for trial 2. For the first sampling date, 15 soil cores $(5 \mathrm{~cm}$ diameter $\times 20 \mathrm{~cm}$ deep) per plot were randomly collected within plots. For the midseason and harvest sampling, both soil and roots were collected. Roots from 15 plants per plot were removed arbitrarily, and the soil surrounding roots was kept for soil extraction. Both soil and roots were placed in plastic bags and stored at $4^{\circ} \mathrm{C}$ until nematode extraction. Nematode population density was estimated by processing two 50-g soil samples from each plot by the modified Baermann pan method (18). Roots were washed, and two 15 -g root samples per plot were placed in a misting chamber for 2 weeks at $22^{\circ} \mathrm{C}$ (17). After the nematode extraction, roots were oven-dried $\left(65^{\circ} \mathrm{C}\right)$ for 2 days and weighed. Nematodes were counted using a stereomicroscope and expressed as numbers per kilogram of soil and numbers per gram of dry root weight.
Statistical analysis. Nematode counts were transformed using $\left[\log _{10}(\mathrm{x}+1)\right]$ before statistical analysis. Data were analyzed by the analysis of variance using the general linear model (PROC GLM) procedure (SAS Institute, Cary, NC). Waller's test was used to compare treatments when the analysis of variance showed significant differences among means $(P \leq 0.05)$. Pearson correlation (PROC CORR) was run between means for the logarithm of the number of $P$. penetrans in tobacco roots at harvest and tobacco yields (SAS Institute).

\section{RESULTS}

In both trials, rotation crops influenced densities of $P$. penetrans in the soil and the roots during the rotation year (Table 1). In 1998 and 1999, average initial nematode densities were 4,258 and 407 per kilogram of soil, respectively. In trial 1 , nematode densities in initial soil samples on 2 June 1998 and midseason root samples on 29 July 1998 were higher under rye than the other crops. Nematode densities in the final soil samples (16 September 1998) were the highest under rye and CGS 7, intermediate under CGPM H6, and the lowest under CFPM 101. In trial 2, based on initial soil densities on 19 May 1999, the plots were uniformly infested with $P$. penetrans. At midseason, soil and root densities (29 July 1999) were lower under

Table 1. Pratylenchus penetrans densities under rotation crops in 1998-1999

\begin{tabular}{|c|c|c|c|c|c|c|c|c|c|c|}
\hline \multirow[b]{4}{*}{ Rotation crop } & \multicolumn{5}{|c|}{ Trial 1 (1998) } & \multicolumn{5}{|c|}{ Trial 2 (1999) } \\
\hline & \multicolumn{3}{|c|}{$\begin{array}{c}P . \text { penetrans } \\
\text { per kg soil }\end{array}$} & \multicolumn{2}{|c|}{$\begin{array}{c}\text { P.penetrans } \\
\text { per g dry root }\end{array}$} & \multicolumn{3}{|c|}{$\begin{array}{c}\text { P.penetrans } \\
\text { per kg soil }\end{array}$} & \multicolumn{2}{|c|}{$\begin{array}{c}\text { P.penetrans } \\
\text { per g dry root }\end{array}$} \\
\hline & \multicolumn{10}{|c|}{ Sampling dates } \\
\hline & 2 June & 29 July & 16 Oct. & 29 July & 16 Oct. & 19 May & 29 July & 8 Sept. & 29 July & 8 Sept. \\
\hline Forage millet (CFPM 101) & $2,443 \mathrm{bA}^{\mathrm{z}}$ & $1,350 \mathrm{bB}$ & $875 \mathrm{cB}$ & $168 \mathrm{bB}$ & $293 \mathrm{cA}$ & $605 \mathrm{aA}$ & 775 bA & $883 \mathrm{bcA}$ & $177 \mathrm{bA}$ & $74 \mathrm{aA}$ \\
\hline Grain millet (CGPM H5) & $\ldots$ & & $\ldots$ & $\ldots$ & 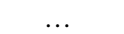 & $198 \mathrm{aB}$ & $680 \mathrm{bA}$ & $758 \mathrm{bcA}$ & $137 \mathrm{bA}$ & $250 \mathrm{aA}$ \\
\hline Grain millet (CGPM H6) & $2,828 \mathrm{bA}$ & $1,825 \mathrm{bA}$ & $1,893 \mathrm{bcA}$ & $126 \mathrm{bB}$ & $367 \mathrm{cA}$ & $363 \mathrm{aA}$ & 743 bA & $1,450 \mathrm{cA}$ & $68 \mathrm{bA}$ & $147 \mathrm{aA}$ \\
\hline Grain sorghum (CGS 7) & $2,500 \mathrm{bA}$ & $710 \mathrm{cB}$ & $3,365 \mathrm{aA}$ & $114 \mathrm{bB}$ & 924 bA & & & & & \\
\hline Rye & $6,635 \mathrm{aA}$ & $4,950 \mathrm{aAB}$ & $3,773 \mathrm{abB}$ & $411 \mathrm{aB}$ & $2,157 \mathrm{aA}$ & $300 \mathrm{aB}$ & $4,617 \mathrm{aA}$ & $3,073 \mathrm{abA}$ & $1,356 \mathrm{aA}$ & $910 \mathrm{aA}$ \\
\hline Rye (to be fumigated) & $6,883 \mathrm{aA}$ & $11,438 \mathrm{aA}$ & $3,893 \mathrm{aB}$ & $644 \mathrm{aB}$ & $3,352 \mathrm{aA}$ & $570 \mathrm{aB}$ & $3,937 \mathrm{aA}$ & $5,160 \mathrm{aA}$ & $1,580 \mathrm{aA}$ & $601 \mathrm{aB}$ \\
\hline Probability $>F$ & 0.0005 & 0.0001 & 0.0016 & 0.0001 & 0.0001 & 0.0653 & 0.0001 & 0.0144 & 0.0001 & 0.4327 \\
\hline
\end{tabular}

${ }^{\mathrm{z}}$ For each extraction method used to estimate nematode population, the logarithm of values within a column followed by the same lowercase letter and within a row followed by the same uppercase letter are not significantly different, as determined by Waller's test $(P=0.05)$.

Table 2. Pratylenchus penetrans densities under flue-cured tobacco crop in 1999-2000

\begin{tabular}{|c|c|c|c|c|c|c|c|c|c|c|}
\hline \multirow[b]{4}{*}{ Rotation crop } & \multicolumn{5}{|c|}{ Trial 1 (1999) } & \multicolumn{5}{|c|}{ Trial 2 (2000) } \\
\hline & \multicolumn{3}{|c|}{$\begin{array}{c}\text { P.penetrans } \\
\text { per kg soil }\end{array}$} & \multicolumn{2}{|c|}{$\begin{array}{c}P \text {. penetrans } \\
\text { per g dry root }\end{array}$} & \multicolumn{3}{|c|}{$\begin{array}{c}\text { P. penetrans } \\
\text { per kg soil }\end{array}$} & \multicolumn{2}{|c|}{$\begin{array}{l}\text { P.penetrans } \\
\text { per g dry root }\end{array}$} \\
\hline & \multicolumn{10}{|c|}{ Sampling dates } \\
\hline & 19 May & 29 July & 8 Sept. & 29 July & 8 Sept. & 15 June & 8 Aug. & 29 Sept. & 8 Aug. & 29 Sept. \\
\hline Forage millet (CFPM 101) & $735 \mathrm{bB}^{\mathrm{z}}$ & $300 \mathrm{dC}$ & $1,753 \mathrm{bcA}$ & $544 \mathrm{bcB}$ & $1,853 \mathrm{aA}$ & $95 \mathrm{aB}$ & $25 \mathrm{cC}$ & $1,363 \mathrm{aA}$ & $158 \mathrm{cB}$ & $858 \mathrm{aA}$ \\
\hline Grain millet (CGPM H5) & & & & & & $130 \mathrm{aB}$ & $323 \mathrm{bB}$ & $1,825 \mathrm{aA}$ & $517 \mathrm{bA}$ & $1,613 \mathrm{aA}$ \\
\hline Grain millet (CGPM H6) & $2,035 \mathrm{abA}$ & $598 \mathrm{cB}$ & $2,980 \mathrm{abA}$ & $595 \mathrm{bcB}$ & 3,764 aA & $173 \mathrm{aB}$ & $250 \mathrm{bB}$ & $1,788 \mathrm{aA}$ & $232 \mathrm{bcB}$ & $2,035 \mathrm{aA}$ \\
\hline Grain sorghum (CGS 7) & $3,240 \mathrm{aA}$ & $1,133 \mathrm{bB}$ & $2,645 \mathrm{bA}$ & $850 \mathrm{abA}$ & $3,176 \mathrm{aA}$ & & $\ldots$ & & & \\
\hline Rye & $4,563 \mathrm{aA}$ & $2,287 \mathrm{aB}$ & $6,385 \mathrm{aA}$ & $1,672 \mathrm{aB}$ & $4,107 \mathrm{aA}$ & $380 \mathrm{aB}$ & $1,235 \mathrm{aA}$ & $2,538 \mathrm{aA}$ & $4,568 \mathrm{aA}$ & $2,687 \mathrm{aA}$ \\
\hline Rye fumigated & $238 \mathrm{cB}$ & $333 \mathrm{dA}$ & $928 \mathrm{cA}$ & $482 \mathrm{cB}$ & $1,447 \mathrm{aA}$ & $35 \mathrm{aB}$ & $118 \mathrm{bB}$ & $2,975 \mathrm{aA}$ & $1,387 \mathrm{bA}$ & $1,801 \mathrm{aA}$ \\
\hline Probability $>F$ & 0.0001 & 0.0001 & 0.0003 & 0.0142 & 0.3315 & 0.4037 & 0.0003 & 0.1898 & 0.0001 & 0.1906 \\
\hline
\end{tabular}

${ }^{\mathrm{z}}$ For each extraction method used to estimate nematode population, the logarithm of values within a column followed by the same lowercase letter and within a row followed by the same uppercase letter are not significantly different, as determined by Waller's test $(P=0.05)$. 
CFPM 101, CGPM H5, and CGPM H6 than with rye.

For trial 1 in 1998, soil densities of $P$. penetrans decreased by $64.2 \%$ during the season in the plots cropped with CFPM $101(P=0.0028)$ (Table 1$)$. Density of $P$. penetrans in roots increased for all treatment crops. For trial 2 in 1999, soil nematode densities under rye and CGPM H5 increased from May to July, but remained unchanged throughout the entire season under CFPM 101 and CGPM H6. In 1999, average density of $P$. penetrans in millet roots ranged from 68 to 250 per gram of dry root and remained constant from July to September. Average nematode densities in rye roots ranged from 601 to 1,580 per gram of dry root and were reduced from July to September in plots of rye to be fumigated.

In the tobacco crop, densities of $P$. penetrans either in soil or in tobacco roots were affected by the previous rotation crop (Table 2). In trial 1, preplanting 19 May 1999 soil nematode densities were highest in plots previously in nonfumigated rye and CGS7, intermediate in CGPM H6, and lowest in CFPM 101 and fumigated rye plots. At midseason (29 July 1999), soil nematode densities were highest under rye and lowest following CFPM 101 and fumigated rye. Thus, the suppressive effect of the forage pearl millet (CFPM 101) and, to a lesser extent, CGPM H6 on populations of $P$. penetrans was detectable 1 year after the rotation crop (trial 1). In 1999, densities of $P$. penetrans under CFPM 101 were similar to those observed in fumigated rye plots. Final soil nematode densities (8 September 1999) were the highest in plots previously grown in nonfumigated rye and the lowest in fumigated rye. In tobacco, final root nematode densities in September were not affected by previous rotation (Table 2 ).

In trial 2, midseason (8 August 2000) soil nematode densities were highest in plots previously grown in nonfumigated rye, intermediate in CGPM H5, CGPM $\mathrm{H6}$, and fumigated rye, and lowest in CFPM 101. Midseason root nematode densities followed the same trend, except CGPM H6 was not significantly different from CFPM 101.

In 1999 (trial 1), soil densities of $P$. penetrans were at their lowest in July for all crops, except the fumigated rye plots, which had the lowest populations in May (Table 2). Root densities of $P$. penetrans in tobacco increased from July to September, except for plots previously grown in sorghum. In 2000 (trial 2), densities of $P$. penetrans in soil were at their lowest level in June and at the highest level in September. In 2000, nematode densities in tobacco roots increased during the growing season in plots previously in CGPM H6 $(P=$ $0.0021)$ and CFPM $101(P=0.0037)$, but did not change significantly in the other previous rotation crops.

The growth of tobacco plants in both field trials was significantly affected by the rotation crops (Tables 3 and 4). In trial 1, plants were tallest following CFPM 101, intermediate following CGPM H6 and fumigated rye, and shortest after nonfumigated rye and CGS 7 (Table 3). Number of leaves was significantly reduced following CGS 7 compared with the other treatments. Tobacco leaf dry weights were increased by 43 and 22\% after CFPM 101 and CGPM H6, respectively, and signifi-

Table 3. Effect of rotation crops on growth of flue-cured tobacco in 1999

\begin{tabular}{lcccc}
\hline & \multicolumn{4}{c}{ Tobacco growth } \\
\cline { 2 - 5 } Rotation crops & $\begin{array}{c}\text { Plant } \\
\text { height }(\mathbf{c m})\end{array}$ & $\begin{array}{c}\text { Leaves } \\
\text { per plant }\end{array}$ & $\begin{array}{c}\text { Leaf dry } \\
\text { weight (kg/ha) }\end{array}$ & $\begin{array}{c}\text { Plant dry } \\
\text { weight (kg/ha) }\end{array}$ \\
\hline Forage millet (CFPM 101) & $126.4 \mathrm{a}^{\mathrm{z}}$ & $16.3 \mathrm{a}$ & $2,847.0 \mathrm{a}$ & $3,999.5 \mathrm{a}$ \\
Grain millet (CGPM H6) & $119.3 \mathrm{~b}$ & $15.7 \mathrm{ab}$ & $2,429.7 \mathrm{ab}$ & $3,300.6 \mathrm{ab}$ \\
Grain sorghum (CGS 7) & $96.5 \mathrm{~d}$ & $13.6 \mathrm{c}$ & $1,181.4 \mathrm{c}$ & $1,503.6 \mathrm{c}$ \\
Rye & $111.0 \mathrm{c}$ & $15.5 \mathrm{~b}$ & $1,992.2 \mathrm{~b}$ & $2,600.6 \mathrm{~b}$ \\
Rye fumigated & $121.0 \mathrm{~b}$ & $16.0 \mathrm{ab}$ & $2,842.8 \mathrm{a}$ & $3,994.5 \mathrm{a}$ \\
Probability > $F$ & 0.0001 & 0.0001 & 0.0002 & 0.0001 \\
\hline
\end{tabular}

${ }^{\mathrm{z}}$ Values within a column followed by the same letter are not significantly different, as determined by Waller's test $(P=0.05)$.

Table 4. Effect of rotation crops on growth of flue-cured tobacco in 2000

\begin{tabular}{|c|c|c|c|c|c|c|}
\hline \multirow[b]{2}{*}{ Rotation crops } & \multicolumn{6}{|c|}{ Tobacco growth } \\
\hline & $\begin{array}{l}\text { Plant height } \\
(\mathbf{c m})\end{array}$ & $\begin{array}{c}\text { Leaves } \\
\text { per plant }\end{array}$ & $\begin{array}{l}\text { Leaf width } \\
\text { (cm) }\end{array}$ & $\begin{array}{l}\text { Leaf length } \\
(\mathrm{cm})\end{array}$ & $\begin{array}{l}\text { Leaf dry weight } \\
(\mathrm{kg} / \mathrm{ha})\end{array}$ & $\begin{array}{c}\text { Plant dry weight } \\
\text { (kg/ha) }\end{array}$ \\
\hline Forage millet (CFPM 101) & $94.3 \mathrm{a}^{\mathrm{z}}$ & $17 \mathrm{a}$ & $24.1 \mathrm{a}$ & $54.2 \mathrm{a}$ & $1,662 \mathrm{a}$ & $2,598 \mathrm{a}$ \\
\hline Grain millet (CGPM H5) & $82.7 \mathrm{~b}$ & $16 \mathrm{~b}$ & $22.6 \mathrm{~b}$ & $50.7 \mathrm{~b}$ & $1,246 b$ & $1,861 \mathrm{ab}$ \\
\hline Grain millet (CGPM H6) & $85.2 \mathrm{~b}$ & $16 \mathrm{~b}$ & $22.4 \mathrm{~b}$ & $51.6 \mathrm{~b}$ & $1,267 \mathrm{~b}$ & $1,906 \mathrm{a}$ \\
\hline Rye & $61.0 \mathrm{c}$ & $14 \mathrm{c}$ & $20.3 \mathrm{c}$ & $45.0 \mathrm{c}$ & $731 \mathrm{c}$ & $1,031 \mathrm{~b}$ \\
\hline Rye fumigated & $82.5 \mathrm{~b}$ & $16 \mathrm{~b}$ & $22.4 \mathrm{~b}$ & $50.8 \mathrm{~b}$ & $1,267 \mathrm{~b}$ & $1,914 \mathrm{a}$ \\
\hline Probability $>F$ & 0.0001 & 0.0001 & 0.0001 & 0.0001 & 0.0001 & 0.0162 \\
\hline
\end{tabular}

${ }^{\mathrm{z}}$ Values within a column followed by the same letter are not significantly different, as determined by Waller's test $(P=0.05)$. 
Table 5. Pearson's correlation coefficient ${ }^{\mathrm{Z}}(r)$ between root Pratylenchus penetrans densities at harvest and tobacco growth data recorded in trial 1 (1999) and trial 2 (2000)

\begin{tabular}{lcc}
\hline & \multicolumn{2}{c}{ Number of $\boldsymbol{P}$. penetrans in roots $(\mathbf{l o g}[\mathbf{x}+\mathbf{1}] \mathbf{g}$ dry root) } \\
\cline { 2 - 3 } Tobacco growth & Trial 1 & Trial 2 \\
\hline Plant height & $-0.4643^{* *}$ & $-0.7509 * * * * *$ \\
Number of leaves & $-0.4079 *$ & $-0.7180^{* * * *}$ \\
Leaf dry weight & $-0.5369 * * *$ & $-0.7029 * * * *$ \\
Plant dry weight & $-0.5404 * * *$ & $-0.6665^{* * * *}$ \\
Leaf width & $\ldots$ & $-0.6838^{* * * *}$ \\
Leaf length & $\ldots$ & $-0.7156^{* * * *}$ \\
\hline
\end{tabular}

z *, $P \leq 0.10 ; * *, P \leq 0.05 ; * * *, P \leq 0.01 ; * * * *, P \leq 0.001$; *****, $P \leq 0.0001$.

that improved growth of tobacco was principally related to the reduced nematode pressure. Previous reports have shown forage pearl millet to be a poor host to $P$. penetrans $(3,6)$, and that rye will increase their densities to damaging levels $(3,5,9,14)$. Forage pearl millet CFPM 101 increases tobacco yields under Ontario's growing conditions (6).

In addition to forage production, forage pearl millet would be beneficial as a green manure crop on the sandy soils with poor inherent soil fertility and low levels of organic matter on which tobacco is traditionally grown. In these field trials, forage millet was cut down twice mechanically with residues returned to the soil each time as green manure. It is recommended the crop be mowed when it reaches a height of 75 to $100 \mathrm{~cm}$, because mature pearl millet residues can be difficult to incorporate in the soil and slow to decompose, and may cause problems during planting and variability in growth of subsequent crops.

While the mechanism of biological control of $P$. penetrans by pearl millet is unknown, Ball-Coelho et al. (1) suggested that it could be related to $\mathrm{S}$-containing compounds. CFPM 101 shoots and roots contained greater concentrations and amounts of $S$ than plants exhibiting little or no suppression (rye). Marigold (Tagetes erecta) is a good alternative to chemical fumigation for Ontario flue-cured tobacco growers to manage $P$. penetrans (16). Pearl millet competes better with weeds, produces greater quantities of biomass, and is more economical than marigold (2).

Future investigations on the poor host suitability of pearl millet should be considered to establish how this crop affects the reproduction of $P$. penetrans. New hybrids of grain pearl millet being developed should be evaluated for their potential to suppress root-lesion nematodes. Results of this study establish that nematodesuppressing grain and forage pearl millet are better rotation crops than the traditional rye or soil fumigation, which is hazardous to human health and the environment.

\section{ACKNOWLEDGMENTS}

We thank Claire Roy and Sylvain Éthier for their dedicated assistance.

\section{LITERATURE CITED}

1. Ball-Coelho, B., Bruin, A. J., Roy, R. C., and Riga, E. 2003. Forage pearl millet and marigold as rotation crops for biological control of root-lesion nematodes in potato. Agron. J. 95:282-292.

2. Banks, S., and Stewart, T. 1998. Forage pearl millet factsheet. Agdex\#: 126.ISSN1198712X, OMAFRA. Queen's Printer for Ontario.

3. Bélair, G., Fournier, Y., Dauphinais, N., and Dangi, O. P. 2002. Reproduction of Pratylenchus penetrans on various crops in Quebec. Phytoprotection 83:111-114.

4. Elliot, J. M., Marks, C. F., and Tu, C. M. 1972. Effects of nematicides on Pratylenchus penetrans, soil microflora, and flue-cured tobacco. Can. J. Plant Sci. 52:1-11.

5. Florini, D. A., and Loria, R. 1990. Reproduction of Pratylenchus penetrans on potato and crops grown in rotation with potato. J. Nematol. 22:106-112.

6. Jagdale, G. B., Ball-Coelho, B., Potter, J.,
Brandle, J., and Roy, C. 2000. Rotation crop effects on Pratylenchus penetrans and subsequent crop yields. Can. J. Plant Sci. 80:543-549.

7. Jagdale, G. B., Roy, R. C., White, P., and BallCoelho, B. 1997. Identification of millet and sorghum hybrids that suppress Pratylenchus penetrans populations. In: Sorghum and Pearl Millet, Annual Report 1997. Agriculture and Environmental Renewal Canada, Inc., Nepean, Ontario.

8. Johnson, P. W., Elliott, J. M., and Marks, C. F. 1982. Effect of fumigant and non-fumigant nematicides on Pratylenchus penetrans populations and yield and quality of flue-cured tobacco in Ontario. Tob. Sci. 26:61-65.

9. MacDonald, D. H., and Mai, W. F. 1963. Suitability of various cover crops as hosts for the lesion nematode, Pratylenchus penetrans. Phytopathology 53:730-731.

10. Marks, C. F., Elliott, J. M., and Tu, C. M 1972. Effects of deep fumigation on Pratylenchus penetrans, flue-cured tobacco, and soil nitrate content. Can. J. Plant Sci. 52:425-430.

11. Meloche, F., Pilon, J.-G., Mailloux, G., and Vrain, T. 1980. Inventaire des problèmes entomologiques et nématologiques dans les plantations de tabac jaune au Québec. Ann. Soc. Ent. Québec 25:81-89.

12. Miller, P. M. 1978. Reproduction, penetration, and pathogenicity of Pratylenchus penetrans on tobacco, vegetables, and cover crops. Phytopathology 68:1502-1504.

13. Olthof, T. H. A. 1971. Seasonal fluctuations in population densities of Pratylenchus penetrans under a rye-tobacco rotation in Ontario. Nematologica 17:453-459.

14. Olthof, T. H. A. 1980. Screening rye cultivars and breeding lines for resistance to the rootlesion nematode Pratylenchus penetrans. Can. J. Plant Sci. 60:281-282.

15. Olthof, T. H. A., Marks, C. F., and Elliott, J. M. 1973. Relationship between population densities of Pratylenchus penetrans and crop losses in flue-cured tobacco in Ontario. J. Nematol. 5:158-162.

16. Reynolds, L. B., Potter, J. W., and BallCoelho, B. R. 2000. Crop rotation with Tagetes sp. is an alternative to chemical fumigation for control of root-lesion nematodes. Agron. J. 92:957-966.

17. Seinhorst, J. W. 1950. De betekenis van de toestand van de grond voor het optreden van aanstasting door het stengelaaltje (Ditylenchus dipsasae) (Kühn) Filipjev). Tijdschr. Plantenziekten 56:291-349.

18. Townshend, J. L. 1963. A modification and evaluation of the apparatus for the Oostenbrink direct cotton-wool filter extraction method Nematologica 9:106-110. 